\title{
HUBUNGAN ANTARA RELIGIUSITAS DENGAN MORALITAS PADA REMAJA DI MADRASAH ALIYAH (MA)
}

\author{
Iredho Fani Reza \\ UIN Syarif Hidayatullah Jakarta \\ Jln. Ir. Haji Juanda No.95. Ciputat Tangerang Selatan 15412 \\ iredhofanireza@rocketmail.com
}

\begin{abstract}
Adolescents who exhibit behaviors according to the prevailing norms and values, the teen said to have morality. While teens who show behavior contrary to the prevailing norms and values, then the teenager is said to commit immoral acts. The results of previous studies, concluded that, individuals need a controller in thinking, behaving, acting, namely religion or religiosity. Religiosity can affect every aspect of an individual's life, both psychologically and physically. This study aims to examine the relationship between religiosity and morality in adolescents at Madrasah Aliyah. This type of research uses a quantitative approach to the type of correlational research. The population numbered 93 students of Madrasah Aliyah 20122013 school year. The sampling technique using simple random technique, the sample in the study totaled 63 students. Analyzed using product moment. The results of this study showed a correlation coefficient ( $\mathrm{r}$ ) of 0.775 with a significance ( $p$ ) of 0.000 , where $p<0.01$. Based on data analysis, the conclusions drawn from this study is that there was a significant relationship between religiosity and morality teen Madrasah Aliyah Boarding Schools in the city of Palembang.
\end{abstract}

Keywords : Morality, Religiosity.

\begin{abstract}
Abstrak
Remaja yang menunjukkan perilaku sesuai dengan norma dan nilai yang berlaku, maka remaja dikatakan memiliki moralitas. Sedangkan remaja yang menunjukkan perilaku bertentangan dengan norma dan nilai yang berlaku, maka remaja dikatakan melakukan tindakan amoral. Hasil-hasil studi terdahulu, menyimpulkan bahwa, individu memerlukan suatu pengontrol diri dalam berpikir, bersikap, bertindak yaitu agama atau
\end{abstract}


religiusitas. Religiusitas dapat mempengaruhi setiap aspek dalam kehidupan individu, baik psikis maupun fisik. Penelitian ini, bertujuan untuk menguji hubungan antara religiusitas dengan moralitas pada remaja di Madrasah Aliyah. Tipe penelitian menggunakan pendekatan kuantitatif dengan jenis penelitian korelasional. Populasi dalam penelitian berjumlah 93 siswa Madrasah Aliyah tahun ajaran 2012-2013. Teknik pengambilan sampel menggunakan teknik random sederhana, sampel dalam penelitian berjumlah 63 santri. Analisis data menggunakan analisis product moment. Hasil penelitian ini diperoleh nilai koefisien korelasi ( $\mathrm{r}$ ) sebesar 0,775 dengan signifikansi ( $\mathrm{p}$ ) sebesar 0,000, dimana $\mathrm{p}<0,01$. Berdasarkan analisis data, kesimpulan yang diambil dari penelitian ini adalah ada hubungan yang sangat signifikan antara religiusitas dengan moralitas remaja di Madrasah Aliyah Pondok Pesantren kota Palembang.

Kata kunci : Moralitas, Religiusitas.

\section{Pendahuluan}

Kemajuan zaman yang serba modern sekarang ini, bisa berdampak positif dan negatif bagi perkembangan remaja, diantaranya perkembangan moral. Remaja yang menunjukkan perilaku sesuai dengan norma dan nilai yang berlaku, maka remaja dikatakan memiliki moralitas. Sedangkan remaja yang menunjukkan perilaku bertentangan dengan norma dan nilai yang berlaku, maka remaja dikatakan melakukan tindakan amoral. Hasil-hasil studi terdahulu, menyimpulkan bahwa, individu memerlukan suatu pengontrol diri dalam berpikir, bersikap, bertindak yaitu agama atau religiusitas.

Hal ini didukung oleh penelitian yang menunjukkan bahwa ada hasil yang konsisten berhubungan antara pemecahan masalah melalui agama atau religiusitas dengan kebahagiaan seseorang (Lewis dan Cruise, 2006). Selanjutnya penelitian yang menunjukkan bahwa pemecahan masalah melalui agama atau religiusitas dapat mempengaruhi gagasan penyesuaian psikososial yang luas (Zwingmann, 2006). Penelitian yang dilakukan oleh Mahmoudi(2007) menunjukkan bahwa ada hubungan signifikan antara kecemasan yang terlihat dan tertutup dengan pemecahan masalah melalui agama atau religiusitas.

Perilaku yang ditampakkan pada masa remaja mengalami banyak perubahanperubahan penting dari aspek fisik maupun psikis. Menurut Hurlock (2009) perubahan fisik pada remaja, ditandai dengan mulai berfungsinya organ-organ 
reproduksi, dan perubahan psikologis yang hampir universal meliputi, meninggi emosi, minat, peran, pola perilaku, dan nilai-nilai yang dianut. Perubahan yang paling mencolok pada remaja, yaitu perilaku serta respon terhadap dunia luar. Menurut Kroh (Dalam Kartono, 2007) perubahan perilaku remaja disebabkan perubahan struktur jiwa. Terjadi kemajuan dalam periode perkembangan dan perubahan yang ditampakkan dalam perilaku, disebut juga dengan masa trotzalter. Perilaku yang ditampakkan oleh seorang remaja mendapatkan penilaian dari lingkungan sekitar. Penilaian dari lingkungan sekitar tersebut memiliki dua nilai, yaitu nilai baik dan nilai buruk. Penilaian dari masyarakat mengenai perilaku yang ditampakkan disebut dengan moral. Menurut Chaplin (2001), moral adalah hal yang menyinggung akhlak, tingkah laku yang susila, ciri-ciri khas seseorang dengan perilaku pantas dan baik, menyinggung hukum, adat istiadat, kebiasaan yang mengatur tingkah laku.

Menurut Poespoprodjo (2009), ada tiga faktor penentu moralitas, pertama perbuatan sendiri, yang dikehendaki individu memandangnya tidak dalam tertib fisik tetapi dalam tertib moral. Kedua, motif yang dimiliki individu dalam pikiran ketika melakukan suatu perbuatan secara sadar dilakukan sendiri untuk dicapai dengan perbuatan sendiri, dan ketiga, keadaan, segala yang terjadi pada suatu peristiwa atau perbuatan. Berdasarkan penelusuran peneliti melalui media massa, didapatkan beberapa fenomena remaja cenderung melakukan tindakan amoral. Dalam Kamus Besar Bahasa Indonesia (2009) amoral diartikan sebagai tidak bermoral atau tidak berakhlak.

Dalam rentang tahun 2013, cenderung banyak terjadi penuruan moral remaja di beberapa Provinsi Republik Indonesia khususnya Kota Palembang dan sekitar. Fenomena yang terjadi salah satunya, perilaku yang cenderung amoral dilakukan oleh seorang pemuda dengan melakukan aksi penjambretan terhadap seorang pejalan kaki. Hal ini dilakukan di salah satu gerbang pusat perbelanjaan daerah kota Palembang (Harian Umum Berita Pagi, 2013). Selanjutnya, fenomena remaja tertangkap warga saat melakukan pencurian ayam di Kelurahan Sungai Buah kota Palembang pada malam hari bersama rekan (Harian Umum Sriwijaya Post, 2013). Begitupun fenomena yang terjadi di Suka Bumi Jawa Barat, siswa SMA terlibat tawuran saat menonton konser musik (Kabar Malam, 2013). Selain itu, fenomena pelajar SMA terjaring razia sedang melakukan perilaku mesum di dalam warnet, hal ini terjadi di Kudus Jawa Tengah (Reportase Pagi, 2013).

Selain fenomena terbaru yang berhasil dihimpun, berdasarkan survei yang dilakukan oleh Komisi Perlindungan Anak (KPA) pada tahun 2008, pergaulan bebas bukanlah suatu yang baru lagi di kalangan remaja. Hasil surrvey di dapatkan, 62,7\% pelajar SMP dan SMA pernah melakukan seks sebelum nikah. 93,7\% remaja sudah 
melakukan ciuman, stimulasi genital, dan oral seks, lalu 97\% remaja sudah pernah nonton film porno. 25\% remaja sudah melakukan aborsi karena hamil di luar nikah. Lebih lanjut, hasil penelitian yang dilakukan oleh Perkumpulan Keluarga Berencana Indonesia (PKBI) pada tahun 2005, menunjukkan 9,1\% pelajar SMP dan SMA di Sumsel pernah melakukan seks (Harian Umum Kabar Sumatera, 2013).

Moralitas ditentukan berdasarkan norma dan nilai yang berlaku di lingkungan masyarakat sekitar. Penilaian baik dan buruk suatu perilaku ditentukan berdasarkan norma dan nilai yang tercipta dan berlaku dalam hubungan sesama lingkungan masyarakat. Menurut Bertens (2007), ciri-ciri nilai moral yaitu perbuatan yang bertanggung jawab, berkaitan dengan hati nurani, mewajibkan, dan bersifat formal. Kohlberg (dalam Thalib, 2010) menyatakan ada tiga tingkat perkembangan moralitas, pertama tingkat prakonvensional, memiliki karakteristik individu melekat pada aturan dan menghargai kepentingan orang lain untuk memenuhi kebutuhan pribadi. Kedua tingkat konvensional, memiliki karakteristik individu mengharapkan hidup terlihat baik oleh orang lain, serta menjaga sistem sosial yang berlangsung. Ketiga tingkat pascakonvensional, memiliki karakteristik individu relatif menjunjung tinggi aturan dalam memihak kepentingan dan kesejahteraan bersama, serta individu mengikuti aturan yang sesuai dengan asas hukum universal. Dalam konteks agama Islam, menurut Yatimin (2007) perilaku yang baik dan pantas disebut dengan akhlak mahmudah yaitu perilaku manusia yang mulia.

Penelitian harus difokuskan maka harus dilihat secara konsep teoritik perbedaan antara akhlak dan moralitas. Menurut Nata (2002), dilihat dari fungsi dan peran dapat dikatakan moralitas dan akhlak sama, yaitu menentukan hukum atau nilai dari suatu perbuatan yang dilakukan manusia, untuk ditentukan nilai baik buruknya, akan tetapi moralitas dan akhlak terdapat perbedaan. Perbedaannya terletak pada sumber yang dijadikan patokan untuk menentukan baik dan buruk. Moralitas bersumber dari kebiasaan yang berlaku umum di masyarakat, sedangkan akhlak berdasarkan al-Qur'an dan al-hadis.

Melihat kenyataan fenomena penurunan moralitas remaja. Maka diperlukan pengontrol bagi perilaku remaja. Menurut Anshori (dalam Ramayulis, 2009), menyatakan bahwa manusia memang membutuhkan suatu institusi yang menjaga atau menjamin berlangsungnya ketertiban dalam kehidupan moral dan sosial, dan agama dapat berfungsi sebagai institusi semacam itu. Dalam hal ini, perlu pengontrolan yang lebih ketat lagi terhadap pembentukan perilaku remaja, salah satunya yaitu dengan pendekatan keberagamaan atau religiusitas. Daradjat (1993) mengatakan, fungsi agama dalam kehidupan manusia adalah, memberikan bimbingan dalam hidup, 
menolong dalam menghadapi kesukaran, dan menentramkan batin.

Menurut Nashori (2002) religiusitas adalah seberapa jauh pengetahuan, seberapa kokoh keyakinan, seberapa pelaksanaan ibadah dan kaidah, dan seberapa dalam penghayatan atas agama yang dianut. Lebih lanjut, Ancok dan Nashori (2008) mengungkapkan religiusitas memiliki lima dimensi, pertama akidah, yaitu tingkat keyakinan seorang Muslim terhadap kebenaran ajaran-ajaran agama Islam. Kedua syariah, yaitu tingkat kepatuhan Muslim dalam mengerjakan kegiatan-kegiatan ritual sebagaimana disuruh dan dianjurkan dalam agama Islam. Ketiga akhlak, yaitu tingkat perilaku seorang Muslim berdasarkan ajaran-ajaran agama Islam, bagaimana berealisasi dengan dunia beserta isinya. Keempat pengetahuan agama, yaitu tingkat pemahaman Muslim terhadap ajaran-ajaran agama Islam, sebagaimana termuat dalam al-Qur'an. Kelima penghayatan, yaitu mengalami perasaan-perasaan dalam menjalankan aktivitas beragama dalam agama Islam. Konsep dimensi-dimensi religisuitas yang diungkapkan Ancok dan Nashori (2008), menggambarkan konsep religisuitas menurut agama Islam.

Berdasarkan pengamatan yang dilakukan peneliti terhadap remaja di Madrasah Aliyah Pondok Pesantren salah satu di kota Palembang. Remaja menampakkan serangkaian perilaku yang cenderung mengindikasikan memiliki moralitas seperti menunjukkan perilaku saling bergotong royong, mematuhi peraturan yang berlaku, perilaku sopan dan satun ditunjukkan dengan hormat kepada guru dan pergaulan yang sehat kepada sesama rekan siswa. Peneliti melihat, masih ada terlihat siswa yang cenderung melakukan tindakan amoral. Selain itu juga, siswa menunjukkan perilaku religiusitas yang ditampakkan melalui serangkaian perilaku ibadah dalam konteks agama Islam. Seperti pelaksanaan salat berjemaah, zikir, membaca al-Qur'an. Akan tetapi, dari hasil pengamatan masih terlihat siswa yang cenderung kurang dalam pelaksanaan religiusitas dalam bentuk perilaku ibadah.

Dari hasil pengamatan di lapangan, mengindikasikan adanya ketimpangan antara kenyataan dengan teori yang ada. Ada sebagian remaja cenderung menampakkan perilaku religiusitas, kenapa masih ada yang cenderung melakukan tindakan amoral. Menurut peneliti, akidah Islam yang dimiliki santri Madrasah Aliyah Pondok Pesantren Ar-Riyadh 13 Ulu Palembang, akan terpelihara jika dilengkapi dengan pengetahuan tentang agama yang di dapatkan santri melalui sumber formal Islam yaitu al-Qur'an dan hadis. Pengetahuan agama yang dimiliki santri cenderung menghasilkan ketaatan terhadap syariah Islam seperti pelaksanaan ibadah shalat, zikir, dan puasa.

Pelaksanaan ibadah yang dilaksanakan santri tidak akan lengkap tanpa pengetahuan tentang agama yang dianut. Karena, dengan melengkapi pengetahuan 
agama, cenderung memperkuat aqidah santri. Ibadah yang dilaksanakan santri juga, harus dilengkapi dengan penghayatan makna yang terkandung dalam pelaksanaan ibadah yang dilaksanakan. Sehingga tercipta kesinambungan antara perilaku ibadah secara fisik dan dirasakan secara psikis serta diaplikasikan melalui perbuatan yang bernilai moral. Dalam hal ini, memperkuat penelitian yang dilakukan peneliti, yang menunjukkan hasil bahwa religiusitas memiliki hubungan yang sangat signifikan dengan moralitas.

Hal ini, selaras dengan penelitian yang menunjukkan bahwa pemecahan masalah melalui agama atau religiusitas memiliki peran yang signifikan sebagai moderator terhadap stres kerja (Safaria, 2011). Selanjutnya kesimpulan dari penelitian, mengungkapkan agama dapat mempromosikan kesejahteraan psikologis. Orangorang dengan iman agama yang kuat memiliki laporan kepuasan hidup yang lebih besar, kebahagiaan pribadi yang lebih besar, dan lebih sedikit konsekuensi negatif peristiwa traumatis kehidupan dibandingkan dengan orang-orang yang tidak religious (Taylor, 2006). Lebih lanjut, penelitian yang menyimpulkan tentang peran agama terhadap kesehatan fisik maupun psikis. Berdasarkan hasil penelitian bahwa komitmen agama dapat mencegah dan melindungi seseorang dari penyakit, meningkatkan kemampuan untuk mengatasi penyakit dan mempercepat penyembuhan (dengan catatan terapi medis diberikan sebagaimana mestinya). Agama lebih bersifat protektif dan pencegahan. Komitmen agama mempunyai hubungan yang signifikan dan positif dengan keuntungan klinis (Hawari, 1997).

Berdasarkan paradigma dari konsep permasalahan yang ada maka tercipta alasan peneliti mengadakan penelitian ini. Dalam penelitian ini, adapun variabel bebas dalam penelitian ini adalah religiusitas, sedangkan variabel terikat dalam penelitian ini adalah moralitas.

\section{Metode Penelitian}

Penelitian ini menggunakan pendekatan kuantitatif dengan jenis rancangan penelitian korelasional, yaitu penelitian yang menyelidiki sejauh mana variasi pada satu variabel berkaitan pada satu variabel lain, berdasarkan koefisiensi korelasi, dengan penelitian korelasional peneliti dapat memperoleh informasi mengenai taraf hubungan yang terjadi (Alsa, 2010). Dalam penelitian ini variabel bebas adalah religiusitas dan variabel terikat adalah moralitas.

Adapun yang dimaksud dengan religiusitas dalam penelitian ini adalah seberapa jauh tingkat pengetahuan, keyakinan, dan tingkat pelaksanaan ibadah, ditampakkan melalui serangkaian perilaku ibadah dalam agama Islam yang dirasakan dengan 
penghayatan pada remaja di Madrasah Aliyah Pondok Pesantren salah satu di kota Palembang. Sedangkan yang dimaksud dengan moralitas dalam penelitian ini adalah kemampuan remaja di Madrasah Aliyah Pondok Pesantren kota salah satu di kota Palembang untuk melakukan penilaian atau pertimbangan terhadap dorongan dalam diri untuk berpikir, bersikap, maupun bertindak dengan rasa penuh tanggung jawab, berdasarkan norma dan nilai perilaku beragama dalam hubungan sesama manusia.

Populasi dalam penelitian ini diambil dari seluruh siswa di Madrasah Aliyah Pondok Pesantren salah satu di kota Palembang yang berjumlah 93 santri. Populasi dalam penelitian ini memiliki karakteristik sebagai berikut:

1) Siswa berjenis kelamin laki-laki, adapun alasan subjek berjenis kelamin lakilaki, dikarenakan di tempat penelitian ini, seluruh siswa Madrasah Aliyah Pondok Pesantren salah satu di kota Palembang, seluruh siswa berjenis kelamin lakilaki, tidak ada siswa berjenis kelamin perempuan.

2) Siswa yang masih aktif mengikuti proses belajar pada tahun akademik 20122013 kelas X (10), XI (11), dan XII (12).

3) Siswa dengan usia remaja 13 tahun sampai usia 18 tahun.

4) Siswa dalam keadaan sehat psikis dan fisik dalam proses belajar.

Teknik pengambilan sampel penelitian dengan menggunakan teknik random sederhana. Menurut Azwar (2011) random sederhana dilakukan dengan cara undian, yaitu mengundi nama-nama subjek dalam populasi. Cara ini diawali dengan membuat daftar lengkap atau nomor subjek yang memenuhi karakteristik sebagai populasi. Nama atau nomor tersebut kemudian diundi untuk mengambil sampel penelitian sebanyak yang diperlukan. Adapun untuk kebutuhan uji coba alat ukur skala penelitian, maka dari 93 populasi penelitian diambil 30 siswa untuk uji coba alat ukur atau try out (TO) dan 63 siswa untuk subjek penelitian. Hal ini dilakukan, mengingat peneliti belum menemukan sekolah sejenis di sekitar tempat penelitian.

Adapun alat pengumpulan data yang digunakan dalam penelitian ini adalah menggunakan skala sikap model Likert yang mengukur konsep psikologis individu. Skala dalam penelitian ini terdiri dari dua skala, yaitu skala moralitas dan skala religiusitas yang dibuat sendiri oleh peneliti berdasarkan konsep teoritiknya. Sebelum skala penelitian digunakan, dilakukan uji coba alat ukur dan dilakukan uji validitas dan uji reliabilitas. Adapun jenis uji validitas yang digunakan adalah validitas konstrak, yaitu validitas yang menunjukkan sejauhmana suatu tes mengukur trait atau konstrak teoretik yang hendak diukurnya. Adapun kaidah dalam menentukan data butir aitem dikatakan valid, berdasarkan pendapat Azwar (2010), analisis butir aitem dikatakan valid dengan melihat kriteria nilai $\mathrm{r}_{\mathrm{ix}} \mathrm{e}$ ” 0,30 maka data butir aitem dikatakan valid. Adapun Teknik uji reliabilitas yang digunakan adalah teknik reliabilitas alpha 
cronbach. Data untuk menghitung koefesien reliabilitas alpha cronbach diperoleh lewat penyajian satu bentuk skala yang dikenakan hanya sekali saja pada sekelompok responden. Dengan menyajikan satu skala hanya satu kali, maka problem yang mungkin timbul pada pendekatan reliabilitas tes ulang dapat dihindari. Menurut Azwar (2010), koefesien reliabilitas $r_{x \times 2}$ yang angkanya dengan taraf signifikan rentang antara $0-1,00$ dikatakan reliabel.

Skala moralitas dibuat berdasarkan pengembangan teori dari Kohlberg(Dalam Danim, 2010) meliputi karakteristik dalam tahap perkembangan moralitas yaitu karakteristik prakonvensional berupa melekat pada aturan dan instrumental: kepentingan nyata individu menghargai kepentingan orang lain. Kedua karakteristik konvensional berupa persetujuan interpersonal : mengharapkan hidup terlihat baik oleh orang lain dan kemudian telah menganggap diri sebagai baik. Ketiga karakteristik pascakonvensional berupa kontrak sosial: relatif menjunjung tinggi aturan dalam memihak kepentingan dan kesejahteraan untuk semua dan etika universal: prinsipprinsip etis yang dipilih sendiri, bahkan ketika ia bertentangan dengan hukum. Untuk skala moralitas, setelah dilakukan analisis seleksi terhadap item skala moralitas yang berjumlah 60 item, diperoleh 43 item yang memenuhi batas minimum $\mathrm{r}_{\mathrm{ix}} \mathrm{e}$ ”, 0,30 dan dianggap valid atau layak digunakan untuk penelitian. Sedangkan 17 item sisanya tidak mencapai batas minimum $r_{\text {ix }}$ e” 0,30 dan dinyatakan gugur atau tidak layak digunakan untuk penelitian.

Sedangkan skala religiusitas dibuat berdasarkan pengembangan teori dari Ancok dan Nashori (2008) meliputi dimensi religiusitas diantaranya dimensi akidah, syariah, akhlak, pengetahuan agama, dan penghayatan. Untuk skala religiusitas, setelah dilakukan analisis seleksi terhadap item skala religiusitas yang berjumlah 60 item, diperoleh 42 item yang memenuhi batas minimum $\mathrm{r}_{\mathrm{ix}}$ e" 0,30 dan dianggap valid atau layak digunakan untuk penelitian. Sedangkan 18 item sisanya tidak mencapai batas minimum $r_{\mathrm{ix}}$ e” 0,30 dan dinyatakan gugur atau tidak layak digunakan untuk penelitian. Analisis data dalam penelitian ini terbagi menjadi dua pengujian, yaitu uji prasyarat dan uji hipotesis. Pengujian prasyarat meliputi uji normalitas sebaran data, adapun kaidah yang digunakan menurut Hadi (2000), jika nilai p > 0,05 maka sebaran data dinyatakan normal, tetapi jika nilai p d” 0,05 maka sebaran data dianggap tidak normal. Dilanjutkan uji linieritas, kaidah uji yang digunakan menurut Hadi (2000), jika nilai $\mathrm{p}<0,05$ maka variabel bebas berhubungan secara linier dengan variabelterikat, namun jika nilai $\mathrm{p}>0,05$ maka variabel bebas tidak berhubungan secara linier dengan variabel terikat.

Tahap Selanjutnya dilakukan pengujian hipotesis penelitian. Untuk menguji 
hipotesis yang diajukan dalam penelitian ini, digunakan teknik analisis korelasi product moment. Tujuan penggunaan analisis ini adalah untuk menentukan hubungan antara religiusitas dengan moralitas yang diajukan dalam penelitian ini. Untuk melihat tingkat korelasi antara dua variabel, berdasarkan kaidah uji hipotesis alternatif penelitian (KUHAP) dalam Hadi (2000):

Tabel 1. KUHAP Alternatif

\begin{tabular}{ll}
\hline Nilai $\mathbf{r}_{\mathbf{x y}}$ & Taraf Signifikan \\
\hline$\tilde{\mathbf{n}}<0,01$ & Sangat singnifikan \\
$\tilde{\mathbf{n}}<0,05$ & Signifikan \\
$\tilde{\mathbf{n}}<0,015$ & Cukup signifikan \\
$\tilde{\mathbf{n}}<0,030$ & Kurang signifikan \\
$\tilde{\mathbf{n}}<0,030 \mathrm{t}$ & Nirsignifikan \\
\hline
\end{tabular}

\section{Hasil dan Pembahasan}

Analisis awal dalam penelitian ini adalah pengujian prasyarat meliputi uji normalitas sebaran data dan uji linieritas. Berdasarkan hasil tabel deskripsi hasil uji normalitas sebaran, maka dapat diketahui bahwa hasil uji normalitas sebaran pada variabel moralitas diperoleh nilai K-S Z sebesar 1,207 dengan nilai signifikansi sebesar 0,108. Artinya pada variabel moralitas $p>0,05$, sehingga dapat dianggap berdistribusi normal. Begitu pula dengan hasil uji normalitas pada variabel religiusitas diperoleh nilai K-S Z sebesar 0,882 dengan nilai signifikansi sebesar 0,418. Artinya pada variabel religiusitas $\mathrm{p}>0,05$, sehingga dapat dianggap berdistribusi normal. Untuk memperjelas hasil pengujian normalitas sebaran data dapat dilihat pada tabel:

Tabel 2. Deskripsi Hasil Uji Normalitas

\begin{tabular}{llll}
\hline Variabel & K-S Z & P & Keterangan \\
\hline Moralitas & 1,207 & 0,108 & Berdistribusi Normal \\
Religiusitas & 0,882 & 0,418 & Berdistribusi Normal \\
\hline
\end{tabular}

Selanjutnya, dilakukan pengujian linieritas data variabel religiusitas dan moralitas, dapat dilihat bahwa nilai signifikansi yang diperoleh adalah sebesar 0,000 dan $\mathrm{R}$ square sebesar 0,601. Hal ini berarti bahwa $\mathrm{p}<0,05$ dan dapat dikatakan antara variabel religiusitas dengan variabel moralitas berhubungan secara linier. Untuk 
memperjelas hasil pengujian linieritas dapat dilihat pada tabel:

Tabel 3. Deskripsi Hasil Uji Linieritas

\begin{tabular}{llll}
\hline Variabel & R square & $\mathrm{P}$ & Keterangan \\
\hline Religiusitas $><$ Moralitas & 0,601 & 0,000 & Linier \\
\hline
\end{tabular}

Setelah uji prasyarat terpenuhi, maka dilakukan pengujian hipotesis dengan uji korelasi product moment. Berdasarkan hasil uji hipotesis, dapat diketahui bahwa koefisien korelasi $\mathrm{r}_{\mathrm{xy}}$ sebesar 0,775 dan nilai signifikansi hubungan kedua variabel adalah 0,000 dimana $r_{x y}=(\tilde{n}<0,01)$. Maka, dapat dikatakan bahwa hipotesis yang diajukan terbukti, bahwa ada hubungan yang sangat signifikan antara religiusitas dengan moralitas remaja Madrasah Aliyah Pondok Pesantren salah satu di kota Palembang. Untuk memperjelas hasil pengujian hipotesis dapat dilihat pada tabel:

Tabel 4. Hasil Uji Hipotesis

\begin{tabular}{llll}
\hline Variabel & $\mathrm{r}_{\mathrm{xy}}$ & Sig. (p) & Keterangan \\
\hline Religiusitas $><$ Moralitas & 0,775 & 0,000 & Sangat Signifikan \\
\hline
\end{tabular}

Nilai signifikansi ( $\mathrm{p}$ ) sebesar 0,000 berarti $\mathrm{p}<0,01$, dapat dikatakan religiusitas dengan moralitas memiliki hubungan yang sangat signifikan. Selaras dengan penelitian yang dilakukan oleh Mahmoudi (2007), hasil temuan dari penelitian berdasarkan analisis statistik menunjukan bahwa ada hubungan signifikan antara kecemasan yang terlihat dan tertutup dengan pemecahan masalah melalui agama atau religiusitas. Selain itu, hasil temuan ini juga selaras dengan penelitian yang dilakukan oleh Safaria (2011), di dapat hasil penelitian menunjukan bahwa pemecahan masalah melalui agama atau religiusitas memiliki peran yang signifikan sebagai moderator terhadap stres kerja.

Berdasarkan dua model kategorisasi subjek penelitian (model perbandingan mean empiris dengan mean hipotetis, dan model distribusi normal), diperoleh temuan bahwa tingkat moralitas dan religiusitas santri berada pada taraf sedang yang cenderung tinggi. Hal ini, dapat menyimpulkan bahwa religiusitas yang dimiliki santri akan mempengaruhi moralitas pada remaja Madrasah Aliyah. Berdasarkan perhitungan kategorisasi skor variabel moralitas, dari 62 sampel penelitian di dapat 46 subjek penelitian atau presentase $74 \%$ berada dalam taraf kategori sedang. Sisanya 16 subjek penelitian atau presentase $26 \%$ berada dalam taraf kategori tinggi, dan untuk kategori rendah hanya $0 \%$ atau tidak ada subjek yang berada 
dalam kategori rendah. Dapat diketahui dari hasil ketegorisasi skor variabel moralitas, bahwa kecenderungan banyak remaja Madrasah Aliyah yang memiliki moralitas dalam taraf sedang berdasarkan perhitungan data statistik. Akan tetapi berdasarkan observasi terhadap remaja Madrasah Aliyah yang dilakukan peneliti, masih ada remaja yang cenderung bertindak amoral.

Remaja Madrasah Aliyah yang memiliki moralitas dilihat berdasarkan karakteristik di dalam tahap perkembangan moralitas. Siswa yang dikatakan memiliki moralitas diantaranya cenderung mematuhi peraturan, solidaritas sesama santri, menjunjung tinggi prinsip-prinsip moral. Menurut peneliti, remaja menunjukkan tindakan yang amoral, hal ini dikarenakan remaja cenderung kurang memahami norma dan nilai pembelajaran moral serta akhlak yang diberikan kepada remaja di Madrasah Aliyah Pondok Pesantren. Pendidikan agama yang di dapatkan remaja Madrasah Aliyah, seharusnya menjadi norma dan nilai yang dianut remaja di dalam kehidupan moral, karena di dalam agama mengandung norma dan nilai yang mengatur semua sistem kehidupan manusia.

Penemuan ini sejalan dengan pendapat Daradjat (1989), kehidupan moral tidak dapat dipisahkan dari keyakinan beragama. Nilai-nilai moral yang tegas, pasti dan tetap, tidak berubah karena keadaan, tempat dan waktu, adalah nilai yang bersumber kepada agama. Dalam pembinaan generasi muda, perlu kehidupan moral dan agama sejalan dan mendapat perhatian yang serius. Hal ini, selaras juga dengan penelitian yang dilakukan oleh Lewis dan Cruise (2006) menunjukan bahwa ada hasil yang konsisten berhubungan antara pemecahan masalah melalui agama atau religiusitas dengan kebahagiaan seseorang.

Selanjutnya, berdasarkan perhitungan kategorisasi skor variabel religiusitas, dari 62 sampel penelitian di dapat 46 subjek penelitian atau presentase $74 \%$ berada dalam taraf kategori sedang. Sisanya 16 subjek penelitian atau presentase $26 \%$ berada dalam taraf kategori tinggi, dan untuk kategori rendah hanya $0 \%$ atau tidak ada subjek yang berada dalam kategori rendah. Dapat diketahui dari hasil ketegorisasi skor variabel religiusitas, bahwa kecenderungan banyak siswa Madrasah Aliyah yang memiliki religiusitas dalam taraf sedang berdasarkan perhitungan data statistik.

Remaja yang dikatakan memiliki religiusitas ditampakkan dengan membaca al-Qur'an, melaksanakan shalat berjemaah, mengetahui jumlah dan isi rukun iman dan rukun Islam, pelaksanaan zikir sesudah shalat dengan khusyuk. Sistem pembelajaran Madrasah Aliyah yang religius terdapat dalam pelaksanaan ibadah, sehingga, norma dan nilai moral yang berlaku cenderung dipengaruhi oleh norma dan nilai yang datang dari ajaran agama Islam. Nuansa remaja menempuh proses 
pendidikan, penuh dengan nuansa religius yang ditampakkan melalui serangkaian pelaksanaan ibadah seperti sholat berjemaah, zikir sehabis sholat dan pembelajaran agama yang diberikan.

Menurut peneliti, antara hasil data analisis yang di dapatkan dengan observasi yang dilakukan terdapat pertentangan. Religiusitas dan moralitas siswa Madrasah Aliyah berdasarkan perhitungan data statistik berada pada taraf sedang yang cenderung tinggi. Berdasarkan hasil analisis data yang di dapatkan, seharusnya antara religiusitas dan moralitas memiliki sinergi yang di aplikasian melalui perilaku yang bemilai moral. Temuan ini, didukung dengan penelitian yang dilakukan oleh Zwingmann (2006), yang mendapatkan hasil yang berbeda. Di dapat hasil penelitian bahwa pemecahan masalah melalui agama atau religiusitas dapat mempengaruhi gagasan penyesuaian psikososial yang luas.

Berdasarkan ulasan data dan hasil temuan dapat diambil suatu simpulan bahwa ketika dimensi keberislaman hadir dalam kehidupan remaja, maka cenderung dalam berpikir, bersikap dan bertindak dalam hubungan sesama manusia akan menjunjung tinggi norma dan nilai agama serta moral pada remaja, sehingga mencegah remaja untuk melakukan tindakan amoral.

\section{Kesimpulan}

Berdasarkan hasil analisis data yang diperoleh, maka dapat disimpulkan bahwa ada hubungan yang sangat signifikan antara religiusitas dengan moralitas remaja Madrasah Aliyah pondok pesantren salah satu di kota Palembang. Religiusitas pada remaja diwujudkan melalui intensitas dari serangkaian pelaksanaan ibadah. Moralitas pada remaja di wujudkan dalam pola berpikir, bersikap, dan bertindak terhadap hubungan sesama manusia yang bernilai moral. Tingkat pemahaman terhadap pelaksanaan ibadah pada remaja akan saling bersinergi dengan tingkat pemahaman norma dan nilai moral pada remaja, apabila dipahami dengan kesungguhan hati nurani. Perilaku yang bernilai moral, berasal dari hati nurani individu. Sehingga semakin tinggi tingkat religiusitas pada remaja akan diikuti tingginya pula tingkat moralitas pada remaja Madrasah Aliyah pondok pesantren salah satu di kota Palembang.

\section{Daftar Pustaka}

Alsa, Asmadi. (2010). Pendekatan Kuantitatif dan Kualitatif dalam Penelitian Psikologi.Yogyakarta: Pustaka Pelajar. 
Ancok, Djamaludin dan Fuad Nashori. (2008). Psikologi Islami. Yogyakarta: Pustaka Pelajar.

Arikunto, Suharsimi. (2010). Prosedur Penelitian. Jakarta: Rineka Cipta.

Azwar, Saifuddin. (2011). Metode Penelitian, Yogyakarta: Pustaka Pelajar. , (2010). Penyusunan Skala Psikologi. Yogyakarta: Pustaka Pelajar. , (1997). Reliabilitas Dan Validitas. Yogyakarta: Pustaka Pelajar.

Bertens, K. (2007). Etika. Jakarta: Gramedia.

Chaplin. (2001). Kamus Lengkap Psikologi. Jakarta:Rajawali Pers.

Danim, Sudarwan. (2010). Psikologi Pendidikan. Bandung: Alfabeta.

Daradjat, Zakiah. (1989). Ilmu Jiwa Agama. Jakarta: Bulan Bintang. , (1993). Peranan Agama Dalam Kesehatan Mental. Jakarta: Haji Masagung.

Djamaludin Ancok dam Fuad Nashori. (2008). Psikologi Islami. Yogyakarta. Pustaka Pelajar.

Fuad Nashori dan Rachmy Diana. (2002). Mengembangkan Kreativitas Dalam Perspektif Psikologi Islam. Yogyakarta: Menara Kudus.

G. Mahmoudi. (2007). Religious Coping And Anxiety In Students Of Islamic Azad University-Sari Branch. Iran: World Applied Sciences Journal.

Hadi, Sutrisno. (2000). Seri Program Statistik-Versi 2000. Yogyakarta: Universitas Gadjah Mada.

Harian Umum Berita Pagi. terbit tanggal 07 April 2013. Palembang, hlm. 13

Harian Umum Kabar Sumatera. terbit tanggal 30 Mei 2013. Palembang, hlm. 1

Harian Umum Sriwijaya Post. terbit tanggal 02 April 2013. Palembang, hlm. 16

Hasan, Aliah B. Purwakania. (2008). Psikologi Perkembangan Islami (menyikapi rentang kehidupan manusia dari Prakelahiran hingga Pascakematian. Jakarta: Rajawali Press.

Hawari, Dadang. (1997). al-Qur'an; Ilmu Kedoteran Jiwa dan kesehatan Jiwa. Jakarta: Dana Bhakti Prima Yasa.

Hurlock, E.B. (2009). Development Psychology, Mc Graw-Hill Inc, Inggris, 1980. 
Diterjemahlan Oleh Istiwidayanti dan Soedjarwo, Psikologi Perkembangan (suatu pendekatan sepanjang rentang kehidupan). Jakarta: Erlangga.

Kabar Malam TV. ONE. tayang pada jam 22.15 WIB. tanggal 06 April 2013

K. Bertens, (2007). Etika, Jakarta: Gramedia.

Lewis, Christopher Alan dan Sharon Mary Cruise. (2006). Religion And Happiness: Consensus, Contradictions, Comments And Concerns, Jurnal Mental Health Religion And Culture, Routledge.

Mujib, Abdul. (2007). Kepribadian Dalam Psikologi Islam. Jakarta: Rajawali Pers.

Najati, M. Utsman. (2008). The Ultimate Psychology Psikologi Sempurna ala Nabi Saw. Terjm. Hedi Fajar. Judul Asli: Al-Hadits an-Nabawi wa Ilm an-Nafs. Bandung: Pustaka Hidayah.

Nashori, Fuad dan Rachmy Diana. (2002). Mengembangkan Kreativitas Dalam Perspektif Psikologi Islam. Yogyakarta: Menara Kudus.

Poespoprodjo. (1999). Filsafat Moral. Bandung: Pustaka Grafika.

Ramayulis. (2009). Psikologi Agama. Jakarta: Kalam Mulia.

Reportase Pagi. tayang pada jam 07.10 WIB. tanggal 11 April 2013

Taylor, Shelley E. (2006). Health Psychology. America, New York: McGraw-Hill Companies, Sixth Edition.

Thalib, Syamsul Bachri. (2010). Psikologi Pendidikan Berbasis Analisis Empiris Aplikatif. Jakarta: Kencana.

Tim Pustaka Phoenix. (2009). Kamus Besar Bahasa Indonesia. Jakarta: Pustaka Phoenix.

Triantoro Safaria. (2011). Peran Religious Coping Sebagai Moderator Dari Job Insecurity Terhadap Stres Kerja Pada Staf Akademik. Yogyakarta: Humanitas Jurnal Psikologi Indonesia Fakultas Psikologi Universitas Ahmad Dahlan.

Yatimin, A. (2007). Studi Akhlak Dalam Perspektifal-Qur'an. Jakarta: Amzah.

Zwingmann, Christian. (2006). Positive And Negative Religious Coping In German Breast Cancer Patients. Journal Of Behavioral Medicine Vol 29, Springer Science + Business Media Inc. 